DOI: https://doi.org/10.32839/2304-5809/2021-8-96-23

УДК 35.071.6(477)

Соломаха А.Г. ${ }^{1}$

Київський національний університет імені Тараса Шевченка

\title{
ДЕЦЕНТРАЛІЗАЦІЯ В УКРАЇНІ: ДОСЯГНЕННЯ, ВИКЛИКИ ТА АКТУАЛЬНІСТЬ РЕФОРМИ
}

\begin{abstract}
Анотація. Досліджено актуальні аспекти практичної реалізації реформи місцевого самоврядування (децентралізації) через призму інституційних викликів та перспектив. У статті наголошено, що ключовим аспектом успішного проведення реформи децентралізації в Україні е взаємодія та співпраця політичних еліт, органів влади, місцевого самоврядування, громадянського суспільства. Водночас, наданий час варто враховувати актуальні виклики щодо інституційного становлення місцевого самоврядування, формування професійних органів управління, формування взаемовідносин органів управління з громадськістю. Автором статті підтримуеться теза про те, що результатом реформи з децентралізації влади має бути дієва система спроможних ОТГ та нових укрупнених районів. Інструментами втілення очікуваного результату мають стати внесення відповідних змін до Конституції та прийняття ряду нормативно правових актів, зокрема запровадження інституту префектів, утворення у районних та обласних рад власних виконавчих органів.
\end{abstract}

Ключові слова: децентралізація, адміністративно-територіальна реформа, об’еднані територіальні громади, місцева влада, місцеве самоврядування.

Solomakha Artem

Taras Shevchenko National University of Kyiv

\section{DECENTRALIZATION IN UKRAINE: ACHIEVEMENTS, CHALLENGES AND RELEVANCE OF REFORM}

Summary. Topical aspects of practical implementation of local self-government reform (decentralization) through the prism of institutional challenges and prospects are studied. The article emphasizes that the key aspect of successful decentralization reform in Ukraine is the interaction and cooperation of political elites, authorities, local governments, civil society. At the same time, the given time should take into account current issues regarding the institutional formation of local self-government, the formation of professional governing bodies, the formation of relations between governing bodies and the public. Topical aspects of practical implementation of local self-government reform (decentralization) through the prism of institutional challenges and prospects are studied. The article emphasizes that the key aspect of successful decentralization reform in Ukraine is the interaction and cooperation of political elites, authorities, local governments, civil society. At the same time, the given time should take into account current issues regarding the institutional formation of local self-government, the formation of professional governing bodies, the formation of relations between governing bodies and the public. The author of the article supports the thesis that the result of decentralization reform should be an effective system of prosperous united territorial communities and new expanded districts. The tool for implementing the expected result should be the introduction of appropriate amendments to the Constitution and the adoption of a number of regulations, including the introduction of the institution of prefects, the formation of district and regional councils of their own executive bodies, and as a result, all levels of local self-government will receive the powers guaranteed by the European Charter of Local Self-Government. Relevant factors for the successful completion of decentralization reform are also the fact that the legislative support of the reform should be accompanied by raising public awareness of the essence of the reform process, its timing, results and competencies for local authorities. The author of the article supports the thesis that the result of the decentralization reform should be an effective system of capable OTGs and new enlarged districts. The tool for implementing the expected result should be the introduction of appropriate amendments to the Constitution and the adoption of a number of regulations, including the introduction of the institution of prefects, the formation of district and regional councils of their own executive bodies, and as a result, all levels of local self-government will receive the powers guaranteed by the European Charter of Local Self-Government. Relevant factors for the successful completion of decentralization reform are also the fact that the legislative support of the reform should be accompanied by raising public awareness of the essence of the reform process, its timing, results and competencies for local authorities.

Keywords: decentralization, administrative-territorial reform, united territorial communities, local authorities, local self-government.

$\Pi$ остановка проблеми. Загальновідомо, що держава як бюрократична інституція не може швидко реагувати на економічні, соціальні, гуманітарні, інфраструктурні та інші сучасні потреби своїх громадян. Актуальні питання життедіяльності найбільш ефективно повинні вирішуватися на місцевому рівні, а саме на рівні громади. Аргументувати цей тезис можна тим, що місцева влада має більше можливостей для вра- хування інтересів своїх жителів, достатньо можливостей для комунікації з ними та оперативного реагування на потреби громади [1]. На сьогодні, Україна мае складну систему адміністративнотериторіального устрою, а саме адміністративнотериторіальні одиниці з різним статусом та різним обсягом повноважень: села, селища, селища міського типу, міста районного та міста обласного значення. Крім того, існують ще більш складні

${ }^{1}$ ORCID: https://orcid.org/0000-0001-9305-7898 
територіальні утворення (так звані «матрьошки»), коли на одній території, паралельно та одночасно фрункціонують окремі адміністративно-територіальні одиниці та одразу декілька місцевих рад, що складає серйозний виклик реформі децентралізації, що з 2015 року розпочала власний інституційний етап становлення [2].

Аналіз останніх досліджень і публікацій. Проблеми децентралізації тривалий час досліджуються відомими науковцями та експертами. Насамперед, слід згадати про В. Оутса, який свого часу сорормулював теорему децентралізації. Головна їі ідея полягає в тому, що «якщо немає економічних переваг (економія від масштабу), пов'язаних із централізованим забезпеченням, то децентралізована модель надання публічних послуг, що враховуе місцеві особливості різних юрисдикцій, буде покращувати добробут порівняно 3 результатами від централізованого надання таких послуг, який характеризується уніфікованими підходами і процедурами в усіх юрисдикціях» [3]. Значний внесок у розроблення теоретичних засад щодо фрункціонування колективних інститутів, створених для управління спільними ресурсами, зробила Нобелівська лауреатка Е. Остром. Зокрема, вона досить переконливо довела, що ефективність використання цих ресурсів залежить від особливостей кожної колективної групи (громади), а також від встановлених правил використання цих ресурсів і контролю за їх дотриманням [4].

3-поміж досліджень окремої уваги заслуговують праці українських та зарубіжних вченихправознавців у галузях теорії держави і права, конституційного та адміністративного права. Зокрема це дослідження таких зарубіжних вчених як: І. Альтузій, Д. Бахрах, Д. Бьолер, М. Варела, С. Кiм, С. Махіна, А. Озмен, В. Протисов, В. Сміт, M. Сомерс, А. Шептулін та ін. Різноманітні аспекти децентралізації були предметом досліджень таких науковців, як Дж. Б'юкенен, Ш. Бланкарт, Я. Брюкнер, Р. Масгрейв, У. Нісканен.

Стосовно українських вчених якісно вирізняються праці М. Баймуратова, Ю. Барабаша, О. Батанова, В. Борденюка, О. Бориславської, К. Бриля, В. Брустінова, В. Величко, І. Грицяка, I. Диниса, I. Жаровської, I. Заверухи, С. Квітки, Т. Карабін, А. Коваленка, В. Ковальчука, І. Коліушка, Я. Лазура, А. Лелеченка, В. Малиновського, А. Матвієнка, М. Менджули, В. Молдована, Р. Натуркач, А. Онупрієнка, Ю. Панейка, О. Петришина, В. Погорілка, Р. Покрови, О. Рогача, В. Романа, М. Савчина, О. Скакун, О. Скрипнюка, І. Сухана, П. Ткачука, І. Хохлова, В. Шаповала, Ю. Шемшученка та ін.

Варто наголосити на внесках ще й інших вчених в розуміння специфріки теми децентралізації на теренах української держави. Так, C. Закірова [5], досліджувала сучасний стан законодавчого забезпечення процесу редормування децентралізації в Україні. В. Венцель [1] аналізував реформу децентралізації в Україні в контексті реалізації соціальної фрункції держави. Аспект просування редорми децентралізащії в умовах поширення пандемї COVID-19, вивчали Ю.Б. Іванов та О.Ю. Іванова [6]. В той же час, експерти Національного інституту стратегічних досліджень, Я.А. Жаліло, О.В. Шевчен- ко, В.В. Романова та ін. [7] в 2019 р. підготували Iрунтовну аналітичну доповідь - «Децентралізація влади: порядок денний на середньострокову перспективу». Доповнити можна і згадкою про дисертаційне дослідження О.В. Ременяк - «Децентралізація публічної влади в правовій теоріі та державотворчій практиці» [8].

Мета статті полягає в актуалізації поточних результатів, викликів та перспектив редорми децентралізащії як складової адміністративно-територіальної редрорми, що триває в Україні з 2015 року та полягає у наданні більших повноважень органам місцевого самоврядування і трансформації адміністративно-територіального поділу.

Викладення основного матеріалу дослідження. В Україні процес децентралізації розпочато 2014 року з прийняттям Концепції редорми місцевого самоврядування та територіальної організації влади в Україні (01.04.2014), законів України «Про співробітництво територіальних громад» (17.06.2014), «Про добровільне об’еднання територіальних громад» (05.02.2015) та змін до Бюджетного і Податкового кодексів - щодо фрінансової децентралізації. Цей процес дозволив формувати відповідно до положень Європейської хартії місцевого самоврядування значний дієвий і спроможний інститут місцевого самоврядування на базовому рівні - об'єднані територіальні громади (ОТГ) [9].

На сьогодні істотною рисою децентралізащіі $€$ те, що вона загалом відбувається на добровільній основі, тим самим сприяючи розвитку місцевої демократії. Значною мірою низовий підхід до розробки структури і створення ОТГ та розробки «перспективних планів» на рівні області означає, що 3 моменту початку об'єднання громад у 2015 році багато українців здобули цінний досвід організації колективних дій, а також ресурси. Вони провели активні дебати щодо місцевих питань та взяли на себе відповідальність за спільне прийняття рішень. Після створення нових ОТГ проводяться місцеві вибори для більш владних органів місцевого самоврядування, відповідальних за розподіл державних коштів та виконання багатьох регуляторних фрункцій, які раніше виконувались регіональними та вищими субрегіональними державними органами [10]. На думку парламентарія В. Безгіна, ключовим результатом просування децентралізації є той фракт, що в усіх громадах ОТГ, які об'єдналися, залишаються $60 \%$ податку на доходи фізичних осіб, 100\% податку на нерухомість, 100\% земельного податку, пряма освітня субвенція, додаткові кошти на розгортання мережі надання адміністративних послуг. Таким чином більше ресурсів і повноважень акумулюються на базовому рівні місцевого самоврядування і водночас суттєво ослаблюється субрегіональний, тобто районний рівень [11].

За 6 років реформи утворено 1070 ОТГ, у які добровільно об’єдналися 4882 громад. 3 них у 936 ОТГ відбулись перші місцеві вибори. Кабінетом Міністрів України затверджено перспективні плани формування територій громад 24 областей, які 100\% охоплюють територію областей. Важливо відзначити, що в 2020 році було узгоджено й затверджено нову конфігурацію ОТГ, після цього було ліквідовано старі й створено нові укрупнені райони. 
За словами Міністра розвитку громад та територій О. Чернишова, надалі, щоб реалізувати можливості децентралізації, необхідно розмежувати повноваження між органами місцевої влади. Для цього потрібно змінити законодавство про місцеве самоврядування та місцеві державні адміністрації [20]. На його думку, доцільним створити виконавчі органи районних та обласних рад, підзвітні та підконтрольні лише цим радам, і перерозподілити повноваження між виконавчими органами рад та районними й обласними державними організаціями таким чином, щоб максимальна кількість повноважень у вирішенні питань місцевого значення була закріплена за виконавчими органами відповідних рад (на сьогодні такі повноваження згідно з чинним законодавствол дублюються органами державної влади та органали місиевого самоврядування) [12].

Станом на другу декаду 2021 року в політичному та експертному середовищі активізувалась дискусія щодо ряду «децентралізаційних законопроектів»: «Про службу в органах місцевого самоврядування» та «Про місцевий референдум». Попередньо обидва мали бути внесені на розгляд Верховної Ради України вже навесні 2021 р., проте на сьогодні дані законопроекти і далі розглядаються в комітетах ВРУ. У цьому контексті слід відзначити, що законопроєкт «Про місцевий референдум» має особливе значення як для розвитку народовладдя, так і запровадження реального контролю громади за органами та посадовими особами місцевого самоврядування. Так, частиною другою статті 78 чинного Закону «Про місцеве самоврядування в Україні» від 21 травня 1997 р. встановлено, що повноваження сільської, селищної, міської, районної в місті ради можуть бути припинені достроково за рішенням місцевого рефререндуму. Водночас порядок проведення місцевого референдуму щодо дострокового припинення повноважень ради визначається законом про місцеві референдуми. Таким чином, единий законний на сьогодні механізм дострокового припинення діяльності зазначених органів місцевого самоврядування заблоковано через відсутність Закону «Про місцевий референдум». ухвалення Закону «Про місцевий рефререндум» в Україні сприятиме поширенню демократичної практики контролю громади за органами й посадовими особами місцевого самоврядування та спонукатиме останніх до більш послідовної роботи на виконання вимог виборців і власних передвиборчих обіцянок [13].

Говорячи про позитивні проміжні результати впровадження реформи децентралізації та ї̈ перспективні вектори подальшої реалізації варто звернути уваги і на актуальні виклики реформи, особливо адміністративно-територіального характеру. Так, головним викликом для децентралізащії до 2019 року в Україні був розрив між амбітною програмою реформаторів та обмеженою інституційною спроможністю для прийняття та реалізації політичних рішень, а також нових законів у попередньо передбачений термін 2014-17 pp. [14]. Після «Євромайдану» політики продемонстрували значний організаторський підхід та чітку волю до впровадження реформи, незважаючи на величезні зовнішні загрози безпеці та пов'язані з ними внутрішні виклики те- риторіальній цілісності України. В той же час, основним досягненням децентралізації стала територіальна консолідація громад та супутне розширення можливостей місцевого самоврядування. Наприкінці 2014 р. та на початку 2015 р. було запроваджено фріскальну децентралізацію та розпочалося об’еднання малих місцевих муніципалітетів у більші та більш самодостатні об'єднані територіальні громади [10].

Наступний етап реформи (2019-2020 роки), що ставив перед собою амбітну ціль - збільшення темпів амальгамації задля того, щоб другий етап об’еднання громад і мав завершитися до загальнодержавних місцевих виборів восени 2020 року був ускладнений політичним календарем 2019 року, який мав три тури загальнонаціонального голосування на виборах президента та парламенту, а також подальшою ротацією персоналу в законодавчій, виконавчій, а також, частково, у судовій владі. Так, наприклад, проект Закону «Про засади адміністративно-територіального устрою України», сформульований тодішнім Міністерством регіонального розвитку, не був розглянутий Верховною Радою перед достроковими парламентськими виборами у липні 2019 р. Цей проект закону забезпечуе правову основу для переформування районів згідно критеріїв, що застосовуються в СС. У ньому було запропоновано перетворити 490 районів (станом на 2019 р.) із середньою чисельністю населення близько 25000 жителів в приблизно 100 нових, кожен 3 яких матиме близько 150000 жителів, без необхідності внесення трудомістких змін до Конституції [10].

В умовах оновлення підходу державної влади до формування районів, змінюеться і їх фонкція. На думку парламентарія, В. Безгіна, райони на сьогодні не є таким важливим. Влада, на сьогодні, за його словами, пропонуе, що там (районні ради) буде безпосередньо державний нагляд, державна координація. Фактично це будуть органи префектурного типу. Як результат, повноваження i pесурс - усе спускається вниз. Райони, на думку Безгіна, не були повноцінно вилучені з адміністративно-територіального устрою України з ряду причин. Перша, це представництво центральних органів виконавчої влади, а отже відкрита доцільність з боку держави захищати суверенітет і конституційність, законність. Наступна причина, координування діяльності різних органів - як представництв міністерств, так і прокуратури, судів і так далі, тобто державна ланка державних представництв на території. Таким чином, робить висновок парламентар: «концентрація всього ресурсу буде з одного боку на базовому рівні, з іншого - де регіональний розвиток і державні стратегії. Це вже обласний рівень, рівень обласної ради, обласної держадміністрації» [11].

Не менш актуальним викликом для просування децентралізації в Україні є питання нагляду за рішенням органів місцевого самоврядування. На думку експертів, ідеальним варіантом було би запровадження інституту префектів, але це вимагає поправок до Конституції, і на даний момент виглядає малоймовірним. Так, зареестрований у парламенті Президентом України проєкт Закону про внесення змін до Конституції України (щодо децентралізації влади) № 2598 від 
13 грудня 2019 р. викликав свого часу критичні зауваження не лише опозиційних до влади політичних сил, а й представників місцевого самоврядування та неурядових організащій. Зокрема, було оприлюднено Спільну заяву міських, селищних, сільських голів, голів об'єднаних територіальних громад та експертів 3 питань децентралізації влади i місцевого самоврядування, в якій зазначено, що «запропоновані законопроєктом № 2598 зміни, порівняно з чинною Конституцією України, містять ознаки централізації влади, звужують статус органів місцевого самоврядування та надмірно розширюють контрольні повноваження держави в особі предектів та Президента» [15].

В цілому варто погодитись 3 експертами в питанні децентралізації про те, що відсутність якісного законодавства, недостатне фрінансування, криза управлінських кадрів та невідповідність державної політики 3 реаліями життя у селах та селищах - основні проблеми, з якими доведеться зіткнутися команді В. Зеленського. 3 основних проблем це і відкрите питання планування територій, так і залучення закордонних інвесторів [16]. Сьогодні існуе серйозна проблема, суть якої - дублювання багатьох фрункцій, які належать до компетенції органів виконавчої влади та органів місцевого самоврядування. Тобто законодавство передбачає, що одні і ті ж самі фрункції виконують як органи виконавчої влади, так і органи місцевого самоврядування. За таких умов виникає конфліктність та невизначеність повноважень між різними гілками влади. Також необхідно ухвалити закони щодо діяльності органів місцевого самоврядування, зокрема, щодо базової структури органів місцевого самоврядування, врегулювання питань оплати праці посадових осіб місцевого самоврядування, установчих та регулюючих документів ОТГ, документів, що регулюють взаємодію з громадськістю, закон про місцевий рефререндум та інші. Одночасно 3 цим необхідно формувати ефективну систему профресійної підготовки кадрів. Зважаючи на нові повноваження та сучасні виклики, важливим елементом інституційного становлення місцевого самоврядування $є$ належний рівень підготовки фрахівців [1, с. 26].

На думку правника М. Тітова, дуже принциповим є питання про закріплення у нормах Конституції України базових повноважень місцевих рад всіх рівнів. Це забезпечить конституційні гарантії здійснення місцевого самоврядування. Експерт переконаний, що наявний районний поділ має бути змінений. Слід врахувати, що після завершення утворення об'єднаних територіальних громад значний перелік повноважень переходить до їх компетенції, а відтак зберігати райради та райдержадміністрації у незмінному стані недоцільно. Крім того, значна кількість ОТГ утворена в межах всього району, що унеможливлюе подальше існування в цих районах районних рад та районних державних адміністрацій [2].

Вчена О. Ременяк в свою чергу виділяе й такі групи проблем у сфері децентралізації публічної влади: ті, що виникають під час перегляду меж адміністративно-територіальних одиниць, що вже має місце на практиці у вигляді укрупнення територіальних громад; проблеми щодо послаблення державного контролю органів місцевого самоврядування за реалізацією повноважень, які будуть їм передані; проблеми бюджетної сcрери 3 питань фрінансування повноважень органів місцевого самоврядування; проблеми з приводу зниження якості місцевого управління та легітимності прийнятих рішень; проблеми щодо утвердження в областях ідей, претензій у сфрері політичних інтересів, які суперечать загальнонаціональним інтересам; проблеми, що зумовлені відсутністю правового закріплення чіткого обсягу повноважень органів публічної влади. На думку, О. Ременяк, важливо аби законодавчий супровід реформи децентралізації супроводжувався підвищенням рівня обізнаності суспільства з суттю процесу редорми, її термінів, результатів та компетентностей для представників місцевої влади в нових адміністративно-територіальних умовах [8].

Вельми цікаво в контексті теми статті буде наголосити на експертних думках щодо актуальних викликів перед територіальними громадами до 2031 року. Останні були отримані в рамках проєкту «Громади України 2031: можливі сценаpiï розвитку». Далі окреслимо, най вірогідніші виклики децентралізації в Україні: 1) Незабезпеченість повноважень органів місцевого самоврядування фінансовими ресурсами та застаріла інфраструктура та мережа соціальних закладів, що не відповідають потребам громади. Невеликі громади потребують значних інвестицій в транспортну індраструктуру та мережі водопостачання та водовідведення. Крім того, мережа закладів освіти потребує оптимізації (Роман Власенко); 2) Великими проблеми стануть питання довкілля - нові вимоги до низько вуглецевої економіки, обмеження доступу до питної води, просування сухих зона на північ, що порушуватиме традиційне сільське виробництво (Анатолій Ткачук); 3) Викликом стане взаємодія між центром та перифрерією громади та взаємодія між мегаполісами та сусідніми громадами (Роман Лозинський); 4) Найбільша проблема - це кадрова. Нині дуже мало підготовлених і готових до роботи спещіалістів. Їх треба навчити, а це складний процес, який стримує розвиток громади. Ще однією проблемою є складнощі з передачею майна, яке $є$ у власності районної ради, але знаходиться на території громади (Віталій Безгін); 5) Недостатне розуміння населенням процесів розвитку громади, а орієнтованість лише на кінцевий результат, виливатиметься у постійне розчарування і створення соціального напруження, чим користуватимуться опонуючі сторони в боротьбі за владу. Рівень переданої відповідальності буде значно вищим за фрінансову спроможність громад, що може призвести до низької якості адміністративних та соціальних послуг (Роман Полікровський); 6) Переведення в онлайн режим: усіх адміністративних послуг, проведення загальних зборів територіальних громад, проведення прийому громадян, Створення та участь в агломераціях (Олександр Слобожан); 8) Інтенсифікація урбанізації. Міста продовжуватимуть зростати і витягуватимуть людський капітал із громад. Зміна клімату та безвідповідальне використання природних ресурсів уже відчуваються 
в Україні та призводять до зміщення природних зон, а в деяких регіонах гостро піднімає проблему доступу до якісної питної води. Слабка або застаріла інфрраструктура, насамперед транспортна, вимагатиме суттевих витрат, які будуть не під силу окремим громадам (Віталій Шпак) [17].

Погоджуємось 3 позицією одного з провідних українських експертів та головних ініціаторів редорми децентралізації А. Ткачуком, який застерігае, що для України життево важливим $€$ дотримання правильної послідовності етапів реалізації плану децентралізації [18]. Ткачук стверджує, пріоритетом має лишатися амальгамація (об’еднання) та розширення можливостей муніципалітетів. Інші нововведення в рамках загальної реформи децентралізації, такі як об’єднання старих районів у більші субрегіональні адміністративні одиниці та створення нового odpicy префректів президента, - далі на черзі. Відповідно до бачення Ткачука щодо подальшого просування реформи, на третьому етапі обласні ради повинні отримати конституційне право створення власних виконавчих комітетів.

Висновки і пропозиції. Редрорма децентралізації посприяла суттевим адміністративно-правовим, фрінансовим змінам на місцях. Зокрема йде мова про зміни, які супроводжувалися передачею місцевим громадам частини матеріальних ресурсів, майна та перерозподілом надходжень від державного бюджету до місцевих бюджетів, що істотно посилило спроможність місцевих громад.

Аналізуючи законодавчі зміні і плани законопроєктної роботи Верховної Ради України на 2020-2021 рр. очевидним є спільність намірів Президента, Парламенту й Уряду стосовно завершення редрорми децентралізації. Разом iз тим попередні спроби внесення змін до Конституції України в частині децентралізації, які не принесли успіху, відсутність узгоджених позицій влади й представників місцевого самоврядування щодо ключових проблемних питань, які стали головним "каменем спотикання», можуть стати суттевими викликами для завершення децентралізації та фріналізації адміністративнотериторіальної редрорми. Погоджуемось, що необхідно упорядкувати систему адміністративнотериторіального устрою таким чином, щоб вона, як у більшості європейських країн, мала, три рівні: базовий - муніципалітет, субрегіональний район, регіональний - область. Реформування місцевого самоврядування повинно сформувати новий тип відносин між громадянами, громадою та державою. Новий формат відносин повинен Iрунтуватися на спільному володінні та спільному управлінні справами громади. Максимальне залучення громадян до управління громадою повинно підвищити ефективність управління, посилити відповідальність за ухвалені рішення та результати їх впровадження. Важливо, щоб мешканці громади були зацікавлені в її добро- буті і не легітимізували можливі фракти перевищення фрункціональної компетентності з боку владних інститутів на рівні громади, району та області.

Децентралізація безперечно є кроком від ідеї та адміністративною структурою, що мали місце бути в радянській Україні. Водночас для уможливлення фріналізації перспективи реформи децентралізащії слід не лише на рівні ВРУ ще до редормування територіально-адміністративного устрою України визначити майбутні фрункції самоврядування на обласному та районному рівнях, а також по-перше, упереджувати «кадровий голод редорми»: мотивувати державних службовців старих (ліквідованих) районів та підтримувати в пошуку нової роботи в ОТГ та інших органах місцевого самоврядування; по-друге, варто предметніше визначити повноваження та відповідальність запропонованих регіональних префектів, що здійснюватимуть державний нагляд за місцевим самоврядуванням не втручаючись у муніципальні справи, але оперуючи консультативною фрункціею щодо ОТГ.

Варто не забувати про вже здобуті переваги редрорми децентралізаціі, а саме розширення повноважень на місцях; громади здобули ресурс, фрінанси, повноваження; право самостійно розпоряджатися фінансами; збільшення бюджетів міст; створення об'єднаних територіальних громад; доступність і якість послуг на місцях. Водночас погоджуемось, що реалізація форсованої децентралізації на основі застосування адміністративного ресурсу не принесе успіху - його забезпечить лише інклюзивний процес, що спиратиметься на вмотивовану участь громад, і насамперед - економічно активного населення та, зокрема, представників бізнес-середовища. Упорядкування адміністративно-територіального устрою і удосконалення системи організації влади - важливі часткові завдання комплексної реформи децентралізації.

На нашу думку, децентралізація в Україні може завершатись прагматично, за умов відповідальної взаємодії парламенту, уряду та громадянського суспільства, якщо актуальні для редорми завдання, а саме: розмежування повноважень органів місцевого самоврядування та органів виконавчої влади; передорматування місцевих держадміністрацій в органи предектурного типу; удосконалення форм міжмуніципального співробітництва громад; зміцнення муніципальної служби; удосконалення фороми залучення жителів до прийняття управлінських рішень місцевого значення; визначення порядку розв'язання питань адміністративно-територіального устрою, не залишаться суто імітацією намірів з боку представників органів державної влади, лобістів централізованої держави та зацікавлення з боку активу об'єднаних територіальних громад.

\section{Список літератури:}

1. Венцель В. Реформа децентралізації в Україні та соціальна функція держави: виклики та перспективи. Аспекти публічного управління. 2020. Т. 8. № 1. С. 18-29. doi: 10.15421/152002

2. Микола Косий. Децентралізація влади - нові виклики. Голос України. URL: http://www.golos.com.ua/ article/330457 (дата звернення: 29.08.2021).

3. Wallace E. Oates. On The Evolution of Fiscal Federalism: Theory and Institutions. National Tax Journal. 2008. Vol. LXI, No. 2, June. P. 313-334. doi: dx.doi.org/10.17310/ntj.2008.2.08 
4. Ostrom E. Governing the Commons: The Evolution of Institutions for Collective Action. Cambridge University Press, 1990. 295 p.

5. Закірова С. Децентралізація в Україні: сучасний стан законодавчого забезпечення процесу рефрормування. Центр досліджень соціальних колунікаиій НБУВ. URL: http://nbuviap.gov.ua/index.php?option=com_con tent\&view=article\&id=2853:detsentralizatsiya-v-ukrajini-suchasnij-stan-zakonodavchogo-zabezpechennyaprotsesu-reformuvannya\&catid $=8 \&$ Itemid $=350$

6. Іванов Ю.Б., Іванова О.Ю. Коронавірус проти децентралізації: ризики та виклики розвитку об’єднаних територіальних громад в умовах пандемії. Проблели еконоліки. 2020. Т. 2. № 44. С. 209-215.

7. Жаліло Я.А., Шевченко О.В., Романова В.В. Децентралізація влади: порядок денний на середньострокову перспективу. Аналітична доповідь. Національний інститут стратегічних досліджень. Київ, 2019. 115 с.

8. Ременяк О.В. Децентралізація публічної влади в правовій теорії та державотворчій практиці : дис. ... канд. юрид. наук : 12.00.01. Львів, 2019. 210 с.

9. Реформа децентралізації. Урядовий портал. URL: https://www.kmu.gov.ua/diyalnist/reformi/efektivnevryaduvannya/reforma-decentralizaciyi (дата звернення: 29.08.2021).

10. Валентина Романова, Андреас Умланд. Досягнення та перспективи реформ децентралізації в Україні 3 2014 року. Вокс Україна. URL: https://voxukraine.org/dosyagnennya-ta-perspektivi-reform-detsentralizatsiyi-vukrayini-z-2014-roku/ (дата звернення: 29.08.2021).

11. Олена Зелінченко. Реформа децентралізації: перспективи та виклики для новостворених громад. Українське радіo. URL: http://www.nrcu.gov.ua/news.html?newsID=94058 (дата звернення: 31.08.2021).

12. Мищак I. М. Законодавче забезпечення місцевого самоврядування в Україні та перспективи його удосконалення. Наукові записки Інституту законодавства Верховної Ради України. 2013. № 1. С. 54-57.

13. Мищак I. Реформа децентралізації в Україні: основні тенденції та перспективи завершення. Конституційний процес в Україні: політико-правові аспекти. 2021. Т. 2 № 82. C. 3-7. URL: http://nbuviap.gov.ua/images/ konstutyciynuy_proces/2021/2.pdf. (дата звернення: 02.09.2021).

14. Concept of the Reform of Local Self-Government and Territorial Organization of Government in Ukraine. Ministry of Foreign Affairs of Ukraine. URL: https://mfa.gov.ua/en/news-feeds/foreign-offices-news/21459-koncepcijareformuvannyamiscevogo-samovryaduvannya-ta-teritorialynoji-organizaciji-vladi-v-ukrajini (дата звернення: 30.08.2021).

15. Спільна заява міських, селищних, сільських голів, голів об'єднаних територіальних громад та експертів з питань децентралізації влади і місцевого самоврядування. Украӥнський кризовий медіацентр. URL: https://uacrisis.org/ua/74427-decentralization-common-statement (дата звернення: 02.09.2021).

16. Наталія Білоусова, Оксана Тупальська. Децентралізація на паузі: 7 викликів президентові Зеленському та його команді. AgroPolit. URL: https://agropolit.com/spetsproekty/573-detsentralizatsiya-na-pauzi-7-viklikivprezidentovi-zelenskomu-ta-yogo-komandi (дата звернення: 01.09.2021).

17. Сергій Волохатий. Які виклики чекають територіальні громади України у найближчі 10 років? Гроладський Простір. URL: https://www.prostir.ua/?news=yaki-vyklyky-chekayut-terytorialni-hromady-ukrajiny-unajblyzhchi-10-rokiv (дата звернення: 02.09.2021).

18. Инна Ведерникова. Автор реформы децентрализации Анатолий Ткачук: “Сейчас нельзя менять Конституцию. Усилим регионы - потеряем страну”. Зеркало Недели. URL: zn.ua/interview/avtor-reformy-decentralizaciianatoliy-tkachuk-seychas-nelzya-menyat-konstituciyu-usilim-regiony-poteryaem-stranu-330506_html (дата звернення: 30.08.2021).

19. Анне Пінтш, Марина Рабінович. Синонім евроінтеграції: як децентралізація наблизить Україну до ЄС. LexInform. URL: https://lexinform.com.ua/v-ukraini/synonim-yevrointegratsiyi-yak-detsentralizatsiya-nablyzytukrayinu-do-yes/ (дата звернення: 01.09.2021).

20. Олексій Чернишов: у 2020 році створено фрундамент децентралізації. Портал "Децентралізація". URL: https://decentralization.gov.ua/news/13065 (дата звернення: 01.09.2021).

\section{References:}

1. Ventsel V. (2020) Decentralization reform in Ukraine and the social function of the state: challenges and prospects. Public administration aspects, t. 8, no. 1, pp. 18-29. DOI: https://doi.org/10.15421/152002

2. Mikola Kosiy. Detsentralizatsiya vladi - novi vikliki [Decentralization of power - new challenges]. Golos Ukrayini. Available at: http://www.golos.com.ua/article/330457

3. Wallace E. Oates (2008) On The Evolution of Fiscal Federalism: Theory and Institutions. National Tax Journal, vol. LXI, no. 2, June, pp. 313-334. doi: dx.doi.org/10.17310/ntj.2008.2.08

4. Ostrom E. (1990) Governing the Commons: The Evolution of Institutions for Collective Action. Cambridge University Press, 295 p.

5. Zakirova S. Detsentralizatsiya v Ukrayini: suchasniy stan zakonodavchogo zabezpechennya protsesu reformuvannya [Decentralization in Ukraine: the current state of legislative support of the reform process]. Tsentr doslidzhen sotsialnih komunikatsiy NBUV. Available at: http://nbuviap.gov.ua/index.php?option=com_content\& view=article\&id=2853:detsentralizatsiya-v-ukrajini-suchasnij-stan-zakonodavchogo-zabezpechennya-protsesureformuvannya\&catid $=8 \&$ Itemid $=350$

6. Ivanov Yu.B., Ivanova O.Yu. (2020) The Coronavirus against Decentralization: Risks of and Challenges for the Development of United Territorial Communities in the context of the Pandemic. The Problems of Economy, vol. 26, pp. 209-215. DOI: https://doi.org/10.32983/2222-0712-2020-2-209-215

7. Zhalilo Ya.A., Shevchenko O.V., Romanova V.V. (2019) Detsentralizatsiya vladi: poryadok denniy na serednostrokovu perspektivu [Decentralization of power: an agenda for the medium term]. Analitichna dopovid. Natsionalniy Institut strategichnih doslidzhen. Kyiv, 115 p.

8. Remeniak O.V. (2019) Decentralisation of the public authority in the legal theory and state-building practice. Thesis for the Candidate of Law Degree. Lviv Polytechnic National University. Lviv.

9. Reforma detsentralizatsiyi [Decentralization reform]. Official website of Ukraine. Available at: https://www.kmu.gov.ua/ diyalnist/reformi/efektivne-vryaduvannya/reforma-decentralizaciyi

10. Valentina Romanova, Andreas Umland. Dosyagnennya ta perspektivi reform detsentralizatsiyi v Ukrayini z 2014 roku [Achievements and prospects of decentralization reforms in Ukraine since 2014]. VoxUkraine. Available at: https://voxukraine.org/dosyagnennya-ta-perspektivi-reform-detsentralizatsiyi-v-ukrayini-z-2014-roku/ 
11. Olena Zelinchenko. Reforma detsentralizatsiyi: perspektivi ta vikliki dlya novostvorenih gromad [Decentralization reform: prospects and challenges for newly created communities]. The National Radio Company of Ukraine. Available at: http://www.nrcu.gov.ua/news.html?newsID=94058

12. Myshchak I.M. (2013) Legislative regulation of the self-government in Ukraine and perspectives for itsimprovement. The Scientific Papers of the Legislation Institute of the Verkhovna Rada of Ukraine, vol. 1, pp. 54-57.

13. Mischak I. (2021) Reforma detsentralizatsiyi v Ukrayini: osnovni tendentsiyi ta perspektivi zavershennya [Decentralization reform in Ukraine: main trends and prospects for completion]. Konstitutsiyniy protses v Ukrayini: politiko-pravovi aspekti, vol. 2, no. 82, pp. 3-7. Available at: http://nbuviap.gov.ua/images/konstutyciynuy_proces/ 2021/2.pdf

14. Concept of the Reform of Local Self-Government and Territorial Organization of Government in Ukraine. Ministry of Foreign Affairs of Ukraine. Available at: https://mfa.gov.ua/en/news-feeds/foreign-offices-news/21459koncepcija-reformuvannyamiscevogo-samovryaduvannya-ta-teritorialynoji-organizaciji-vladi-v-ukrajini

15. Spilna zayava miskih, selischnih, silskih goliv, goliv obednanih teritorialnih gromad ta ekspertiv z pitan detsentralizatsiyi vladi i mistsevogo samovryaduvannya [Joint statement of city, settlement, village mayors, heads of united territorial communities and experts on decentralization of power and local self-government]. Ukraine crisis media center. Available at: https://uacrisis.org/ua/74427-decentralization-common-statement

16. Nataliya Bilousova, Oksana Tupalska. Detsentralizatsiya na pauzi: 7 viklikiv prezidentovi Zelenskomu ta yogo komandi [Decentralization on pause: 7 challenges to President Zelensky and his team]. AgroPolit. Available at: https://agropolit.com/spetsproekty/573-detsentralizatsiya-na-pauzi-7-viklikiv-prezidentovi-zelenskomu-ta-yogokomandi

17. Sergiy Volohatiy. Yaki vikliki chekayut teritorialni gromadi Ukrayini u nayblizhchi 10 rokiv? [What challenges await the territorial communities of Ukraine in the next 10 years?] Gromadskiy Prostir. Available at: https://www.prostir.ua/?news=yaki-vyklyky-chekayut-terytorialni-hromady-ukrajiny-u-najblyzhchi-10-rokiv

18. Inna Vedernikova. Avtor reformyi detsentralizatsii Anatoliy Tkachuk: "Seychas nelzya menyat Konstitutsiyu. Usilim regionyi - poteryaem stranu" [The author of the decentralization reform Anatoly Tkachuk: "Now the Constitution cannot be changed. We will strengthen the regions - we will lose the country"]. ZN.UA. Available at: zn.ua/interview/avtor-reformy-decentralizacii-anatoliy-tkachuk-seychas-nelzya-menyat-konstituciyu-usilimregiony-poteryaem-stranu-330506_.html

19. Anne Pintsh, Marina Rabinovich. Sinonim Evrointegratsiyi: yak detsentralizatsiya nablizit Ukrayinu do ES [Sinonim Eurointegratsii: how decentralization brings Ukraine closer to the EU]. LexInform. Available at: https://lexinform.com.ua/v-ukraini/synonim-yevrointegratsiyi-yak-detsentralizatsiya-nablyzyt-ukrayinu-do-yes/

20. Oleksiy Chernyshov: the decentralisation basis was created in 2020. Portal «Detsentralizatsiya». Available at: https://decentralization.gov.ua/news/13065 